\title{
ФУНКЦІОНАЛЬНО-КОМУНІКАТИВНИЙ ПРОСТІР В УКРАЇНСЬКОМУ ЩОДЕННИКОВОМУ ДИСКУРСІ
}

\begin{abstract}
Ігнатьєва С. Є. Функціонально-комунікативний простір в українському щоденниковому дискурсі.

Визначено емпірично виокремлені способи організації комунікативного простору в українському щоденниковому дискурсі, виявлено типи щоденникової комунікації, простежено лінгвопсихоментальну діяльність комуніканта-продуцента й, комуніканта-реципієнта у процесі інформаційного обміну та взаємовпливу за допомогою знаків природної мови.

Ключові слова: комунікативний простір, автокомунікація, наративний комунікант, комунікант-продуцент, комунікант-реципієнт, процес комунікації.
\end{abstract}

Игнатьева С. Е. Функционально-коммуникативное пространство в украинском дневниковом дискурсе.

Определены эмпирийно виделеные способы организации коммуникативного пространства в украинском дневниковом дискурсе, выявлены типы дневниковой коммуникации, прослежена лингвопсихоментальная деятельность коммуникантапродуцента и коммуниканта-реципиета в процессе информационного обмена и взаимовлияния с помощью знаков природного языка.

Ключевые слова: коммуникативное пространство, автокоммуникация, нарративный коммуникант, коммуникант-продуцент, коммуникант-реципиент, процесс коммуникации.

Ignat'yeva S. Functional-communicative space in the diary discourse.

There are determined empirically defined methods of organizing the communicative space in Ukrainian diary discourse, the types of diary communication are revealed, is traced the lingual psycho and mental activity of the communicant-producer and communicant recipient in the process of exchange of data carriers and reciprocal effect with the aid of the signs of natural language.

Key words: space, auto-communication, narrative communicant, communicantproducer, communicant-recipient, the process of communication.

3 початку XX століття тема комунікації привертає увагу мовознавців, що сприяє виокремленню нового напрямку - комунікативної лінгвістики. Основна увага сучасних лінгвістів зорієнтована передусім на дослідження функціонального аспекту мови як засобу вербальної комунікації, певної структури людського існування, у просторі якої відбуваються основні види їі діяльності. Вивчення мови в динаміці, у русі

(c) С. Є. Ігнатьєва, 2012. 
від загального коду у формі узуальних знаків до їхньої реалізації в умовах конкретних комунікативно-прагматичних ситуацій, від системи номінативних знаків до функціонування їх у мовленні уможливлює глибше проникнення в іiі системність, адже пізнати мову поза іiі функціонуванням неможливо. У сучасних розвідках практично за межами комунікативної лінгвістики залишається дослідження щоденникового дискурсу (ЩД), який, як показове явище сучасного комунікативного простору, становить цікавий і зовсім не вивчений об'єкт дослідження. Основна увага дослідників щоденника, зокрема українських, зорієнтована здебільшого на концептуально інші аспекти його вивчення (зокрема літературознавчий, історичний, культурологічний, психологічний тощо). 3 огляду на це, ЩД потребує багаторівневого вивчення, яке б сприяло об' єктивному визначенню його справжнього місця у функціонуванні духовної сфери буття людини й суспільства в цілому.

Наукова новизна отриманих результатів полягає у тому, що на засадах комплексного підходу вперше в українському мовознавстві зроблено спробу дослідити функціонально-комунікативний простір у ЩД, зокрема простежено лінгвопсихоментальну діяльність комунікантапродуцента й комуніканта-реципієнта у процесі інформаційного обміну та взаємовпливу за допомогою знаків природної мови.

Особлива увага науковців до теоретичних проблем спілкування пояснюється значною кількістю праць, присвячених таким поняттям як текст, дискурс (Р. Барт, А. Д. Бєлова, Р. Водак, С. В. Воркачев, В. З. Дем'янков, В. І. Карасик, В. В. Красних, З. Д. Попова, О. О. Селіванова, К. С. Серажим, Г. Г. Слишкін, Ю.С. Степанов, I. С. Шевченко та ін.). Російська мовознавець О.С. Кубрякова, виокремлюючи когнітивно-дискурсивну парадигму, зауважує, що «теоретично усвідомлюючи нову парадигму, за своєю суттю функціональну, описуючи кожне мовне явище, як правило, враховуються ті дві функції, які вони обов'язково виконують - когнітивну (за їх участю у процесі пізнання) і комунікативну (за їх участю в актах мовленнєвого спілкування)» [11, с. 6-17]. Комунікація розглядається науковцями як своєрідний простір, інструмент i принцип культури, завдяки яким здійснюється міжкультурний діалог. Зважаючи на структуру й принципи організації комунікації, Ю.С. Прохоров називає три елементи іiі архітектоніки: дійсність, текст і дискурс. Також вчений стверджує, що зазначене поняття - явище просторове [18, с. 84]. Водночас М. М. Бахтін зазначає, що «мова може існувати в дійсності тільки у формі конкретних 
висловлювань окремих мовців, суб'єктів мови. Мова завжди відлита у форму висловлення, що належить певному мовному суб' єкту, і поза цією формою існувати не може. Якими б не були різними висловлення за своїм обсягом, змістом, композиційними побудовами, для них, як одиниць мовного спілкування, властиві загальні структурні особливості й водночас абсолютно чіткі кордони» [1, с. 170].

Сучасне мовознавство поки що не має у своєму розпорядженні однозначного тлумачення терміна «простір». Його активно вживають лінгвісти, соціологи, історики, культурологи, використовуючи назви «ментальний простір», «мова і її концептуальний простір», «мовленнєвий простір», «інформаційно-комунікативний простір» та ін. Основним поняттям для будь-якого виду комунікації є визначення комунікативного простору. Щодо терміна «комунікативний простір», то він не має стійкого та однозначного тлумачення. Н. В. Муравйова під комунікативним простором розуміє рівень комунікативної компетенції адресанта чи адресата [15, с. 134], у загальній теорії комунікації Г.Г.Почепцов цей термін розширює до поняття інформаційного простору [17, с. 98], Б. М. Гаспаров визначає комунікативний простір швидше за все як простір дискурсивний [7, с. 231]. I. П. Сусов вводить поняття «комунікативно- прагматичний простір», визначаючи його як мовленнєву ситуацію, що охоплює ролі мовця i слухача, характеристики часу і місця, правила узгодження цих цілей у рамках кооперативного принципу, правила передачі ролі мовця від одного комуніканта іншому і т. ін. [22, с. 67]. Принципово важливою рисою є те, що при будь-якому тлумаченні комунікативного простору точкою відліку в ньому завжди є адресант.

Узагальнюючи поняття комунікативного простору, ми розглядаємо його як поле реальних і потенційних контактів між учасниками комунікації у ЩД - продуцента й реципієнта. Вступаючи у комунікативні відносини, кожен з учасників спілкування має свій погляд на процес комунікації, свої ціннісні орієнтири й власні судження про той чи інший предмет мови, а також розуміє свою роль у цьому процесі. Очевидно, що комунікативний простір багатомірний, рухливий, мінливий, його неможливо структурувати, принаймні, однозначно.

У сучасному світі саме інформація і знання постулуються як основні цінності. Ми переживаємо час самопізнання, часом складного 
і хворобливого, пізнання своєї історії, міфів, кумирів, помилок тощо. Щоденник сьогодні є необхідним складником індивідуального буття людини, а щоденниковий дискурс сприймається реципієнтом як одна iз форм комунікації, що передбачає активне спілкування певної соціальної структури 3 накопиченим культурним досвідом, а також становить один із основних засобів духовного самовизначення особистості, виробленню власної ідентичності. Він посідає помітне місце у літературно-художніх i суспільно-політичних виданнях останніх десятиріч, а також слугує джерелом знань і мудрості. Окрім того, через ЩД отримуємо відомості стосовно історичних подій, побут i звичаї, які характеризують певну епоху. У контексті культурно-діяльної психології, створеної Л. С. Виготським, О. М. Леонтьєвим і О. Р. Лурією, щоденниковий дискурс, мабуть, є одним із найвиразніших претендентів на те, щоб слугувати «глечиком особистості» за межами людської свідомості. У щоденниковому жанрі найповніше виявляються особистісні смисли, «значення-для-мене» [13, с. 121]. На думку багатьох учених, мовленнєва структура ЩД підпорядкована так званій безадресній стратегії, фактор відсутності адресата розглядається як визначальний «режим щоденникової діяльності» [13, с. 103]. На думку О. О. Селіванової, «У комунікативній ситуації відбувається розщеплення особистостей комунікантів: адресанта й адресата. Особистість комуніканта в дискурсі представлена, по-перше, реальним комунікантом; по-друге, функцією комуніканта як відображенням його позиції, світогляду, мети, стратегій у знаковій формі повідомлення, тексту; по-третє, інтерпретованим комунікантом як рефлексією у свідомості комуніканта уявлення про партнера спілкування та його функцію у повідомленні, тексті. За умови перемикання кодів і пристосування комуніканта до певної ролі, не властивої їй як людині, варіативність розщеплення збільшується. Можливо, додатково вводиться наративний комунікант як програма оповідача в повідомленні 3 його функцією в повідомленні» [21, с. 597]. 3 огляду на це, на відміну від епістолярної комунікації, щоденникова не передбачає послідовної зміни ролей: продуцент - реципієнт. У ЩД відсутній зворотній зв’язок. Комунікант-продуцент (К-П) у майбутньому (через роки, десятиліття, а, можливо, й століття) може лише сподіватися на реакцію К-Р. На основі типів комунікації та інших характеристик комунікативного процесу виділяють різні види комунікації. Так, Г.Г.Почепцов пропонує розрізняти комунікацію за кількістю 
співрозмовників. Учений виокремлює внутрішню комунікацію (розмова 3 самим собою), міжособистісну (розмова між двома людьми) [17, с. 223]. Щодениковий дискурс - це своєрідна «автокомунікація», коли продуцент сам говорить із собою. Саме в ЩД уможливлюється те, що Л. Виготський називає феноменом «внутрішнього мовлення». Цей діалог із собою вибудовується за законами, близькими до законів цього феномену. ЩД - це передусім особистісний простір продуцента, який водночас конструює свою особистості, вибудовуючи власне «Я». К-П активно формує себе через власне сприйняття навколишнього світу. Отже, вибудовування свого «Я» вимагає насамперед активного пошуку заманіфестованої інформації. Комунікант-продуцент і комунікант-реципієнт (К-Р) у ЩД існують і діють у різних типах ситуацій. У ЩД $є$ два учасники комунікації: «пише» (адресант, продуцент мови) і «читає, сприймає» (адресат, реципієнт). На першому етапі продуцент i реципієнт виступають в одній особі. Кожен з учасників комунікації залучений у процес вербалізації (практичного використання мови), що є частиною більш широкого, розумового процесу, який охоплює відтворення та інтерпретацію мовної ситуації, формулювання цілей (інтенцій), а також складання і приведення у виконання планів (комунікативних стратегій і тактик) для їх досягнення [5, с. 295].

Насправді, ЩД - платформа для вираження не тільки особистості, але і іiі динамічного розвитку. Безадресна мовленнєва діяльність, у якій відсутній експлікований К-Р, є найважливішою жанротворчою ознакою ЩД. Зауважимо, що вживаючи поняття «відсутність адресата», «неадресність щоденникових записів», як правило, маємо на увазі відсутність «справжнього адресата», оскільки «під час ведення щоденникових записів суб’єкт і адресат комунікації представляються в одній особі», що надає висловленню «автокомунікативності» [20, с. 102]. Безсумнівно, така автокомунікативність є цілком закономірною. «Безадресність» стає умовною, і ЩД розглядаємо як «спілкування адресанта з самим собою», це «текст парадоксальним чином до самого себе <... >. Йому властивий момент проповіді, але це проповідь собі, це момент сповіді, але це сповідь перед самим собою. Насамкінець, це розмова з собою» [16, с. 204]. Як зауважує Ю. М. Лотман, у процесі такої комунікації відбувається «переформування самої особистості» $[14$, c. 36]. Перечитуючи власні думки і відчуття через певний час, 
К-П, як правило, до своїх же думок ставиться критично, сперечається 3 собою вчорашнім або навпаки погоджується з уже написаним. Це і автокомунікація - діалог 3 собою. У цьому разі ЩД постає як продуктивний процес формування ідентичності, дозволяє розкрити своє, особливе, за допомогою усього розмаїття «інтимності» інформації про себе - від публічної і відомої для всіх до найпотаємнішої і сокровенної. Настільки правильно К-П інтерпретуватиме запропоновану для К-Р інформацію і відповідним чином відреагує на неї - залежить насамперед від його компетенції, від уміння співвіднести цей чи інший факт з реальною дійсністю, а, можливо, й розкодувати, розшифрувати іiі. Поза будь-яким сумнівом, це дає нам підстави виокремити такі типи щоденникової комунікації:

1) однонаправлену: лінійну - одному комуніканту-продуценту, який одночасно $є$ комунікантом-реципієнтом (насамперед собі, сповідь перед собою, спілкування з білим аркушем паперу);

2) радіальну - різним комунікантам-реципієнтам (К-П сподівається, що його сповідь у майбутньому буде надруковано, стане загальнодоступною і цікавою для К-Р).

Презентуючи внутрішне мовлення в ньому найвиразніше простежується мотиваційний «план свідомості», (там же) «поліфонія свідомості», про яку наголошує М. М. Бахтін. А дискурс, на думку Тойн А. ван Дейка, якраз і буде тією комунікативною подією, «яка відбувається між тим хто говорить і тим, хто слухає (спостерігає тощо) у процесі комунікативних дій у певному часовому, просторовому та іншому контексті. Вона може бути мовленнєвою, письмовою, мати вербальні й невербальні складники» [4, с. 227]. Філософське положення про діалогічність буття (сутність людини, людського «Я» відкривається тільки тоді, коли вона звертається до «Іншого», істина буття перебуває між ними, адже «Я» нічого про себе не може сказати без «Іншого» - за М. Бубером [3, с. 296]. Р. Барт виокремлює метонімічний (розповідний) тип дискурсу [2, с. 198]. Отже, спираючись на класифікацію французького вченого, визначаємо такі емпірично виокремлені способи організації комунікативного простору в щоденниковому дискурсі розповіді про своє життя:

\section{Емоційно-метафоричний (перформативний спосіб) -} щоденниковий запис створюється як опис події (спогад, спомин, сповідь), який конструюється 3 «випадків»: ліричних, комічних, трагічних, драматичних, які супроводжуються переживаннями, 
оцінками, запитаннями, проханнями, звертаннями; це певне «наяву» тих життєвих фрагментів, які вже сталися, свідком яких автор був і які вразили його уяву. Напр.: Шевченківські свята. Враниі вітав сьогорічних шевченківських лауреатів. Багато зарубіжних гостей. Китайський професор Ге Баоиюань привіз «Собор» китайською мовою. В опері урочистий вечір. Навіть душитель заговорив українською... Концерт чудовий. Але й сумно... [9, (т. 3, с. 226)]; Давно колись, піонером, слухав 9-ту симфонію Бетховена. Враження було сильне, особливо від кіния, хоч я нічортечички і не розумів (просто, дія на почуття; іноді це $\epsilon$ найкрашим мірилом речі - не «забруднено» тлумаченнями [10, с. 302]; Дивилися з Нелею «Майстра и Маргариту» в Театрі на Таганиі. Нi Майстра, ні Маргарити там нема, але с прекрасна вистава, яка триває майже чотири години, дивишся як заворожений [23, с. 391]; А зараз по свіжій пам'яті фіксую мамину сповідь-рану про голодовку. Так, так про голодовку в ту сторозпрокляту колективізаційну пору. Лихо було таке страшне, щз я, почувши вперше про нього (досі мама боялася за мене, щоб «нерви не надірвав» або десь не пробалакався), - не знаходжу спокою [6, с. 5].

Настановчий (дидактичний) спосіб - життєві факти відтворюються як притча чи апокриф, як «заповіт», як «приклад» (мужності, героїзму, терпіння, служіння народу, Вітчизні, доброчесності, терпеливості, непохитності, непоборності, принциповості, бездоганності тощо), які імпліцитно становлять «гордість» оповідача i містять висновки, побажання, повчальні висловлювання, «моралітет». Напр.: Через 30 років після війни знов доводиться воювати, на ичей раз - проти хамства. Дрімучого, зажсирілого... Саме з ним сьогодні витримав складний бій, хоча й коштувало це немало нервів. I, мабуть, так, на вогневих, доведеться бути до кінця жнття. Бо тільки трохи приспокойсь, уже тут як тут вони, чиновницьке хамство і тупість, щоб принизити тебе, поглумитись. А тільки даси одкоша - одразу ж виявляють свою боягузливість. На знак протесту проти чиновницької розперезаності, попри запізнілі їхні вибачення не пішов і до Палацу «Україна» на казенне засідання. Замість того сиджу оце на Володимирській гіриі, $i$ слухаю гул Подолу, $i$ вбираю очима задніпровську задимлену далеч.. Вітряно й просторо. Тут чути вічність [8,(т.2, с.218)]; Сидимо поряд з Олегом Антоновим, авіаконструктором. Вчора, каже він, мав розмову з якимись чехами 
на літер[атурні] теми, дійшли висновку, щзо найкращий твір про війну - «Пра[поронос]ці». Не знаю, чи не ради компліменту сказано, та все жс присмно [8, т. 2, с. 218)]; Окопна філософія: не висовуйся - вочевидь, не для мене. Я той, що йде в атаку відкрито [6, с. 901].

Аналітико-телеологічний (ентимематичний) спосіб - запис створюється як опис цілеспрямованого руху до якоїсь знаної / незнаної мети, яка постійно відкривається і містить детальні висновки, прийняті рішення, усвідомлення планів, оцінку досягнень: Я майэке певен: якби Гоголь не порвав із свойм національним середовищем, якби зберіг $i$ надалі ті родинні зв'язки, щчо його жсивили в юності $і$ ще раніш у дитинстві, - не закінчив би він так трахічно. Втративии Украӥну, він опинився в духовному вакуумі. Він задихався від нестачі повітря. Звідси його містика, муки, страждання, почуття найчорнішої безвиході...<..> Шевченко майже стільки літ, як $і$ Гоголь, $і$ так само більший відтинок свідомого життя провів поза Україною. Але він зберіг всі духовні зв'язки, зберіг у повноті, рівній реальному середовищу все дороге, заповітне й наснажнливе, $i$ тому не сталося з ним того, щзо сталося з Гоголем: при всіх свойх терзаннях Шевченко уник тієі внутрішньої спустошливої, руйнівної кризи, яка задушила його великого земляка, перед тим спаливши на чорнім вогні розпуки його не відомі для нас творіння. Ось це все могло б стати основою твору: «Гоголь у Римі» або «Гоголь у Венеції» [8, (т. 2, с. 273)]; Я довго, я дуже довго карався $\boldsymbol{i}$ мучився, принижувався й свідомо недооцінював себе: весь час здавалося, щу ті, хто старші роками, маючи більиий часовий життєвий досвід, були розумнішими. Плюсом однак вважаю: я ніколи не втрачав у себе віру. Зараз, у полудневому віці, нарешті стаю «дозрілим плодом» [6, с. 969]. Так описують події автори, які хочуть підкреслити, що вони selfmade, що всім у житті вони зобов'язані собі самому.

Важливим складником комунікативного простору в ЩД $\epsilon$ уявлення комуніканта-продуцента (К-П) про реального чи потенційного комуніканта-реципієнта (К-Р). У процесі декодування імплікатури провідним чинником $є$ комунікативний намір реципієнта, його бажання виявити додаткову інформацію про ситуацію, часто імпліцитно виражену в тексті. Комунікація у спілкуванні - це насамперед канали, якими відбувається обмін інформацією - візуальною, вербальною, ментальною, асоціативною. В особистому щоденникові продуцент насамперед ділиться інформацією із собою. Інформація про навколишній світ 
обов'язково повинна відображати власне «Я». Будь-яка ретрансляція інформаційної картини ще й спонукає до іï інтерпретації Інформація представляється через призму бачення продуцента, яке відоме під назвою «framing» (вибір обрамлення). Особливість ЩД якраз і становить Яцентричність репрезентації картини світу. Сам факт обирання тієї чи іншої події для опису вже містить значний інформаційний заряд. Це «agenda setting», тобто визначення «порядок денний» у контексті конструювання власної особистості. Безсумнівно, що представлення певних подій у ЩД - це мозаїка навколишнього світу, яка охоплює не тільки цей світ, але й нас самих. Потенційні засоби «особистісного контенту» у ЩД представлені з одного боку, глибиною внутрішнього світу комуніканта-продуцента, його думками, сумнівами, емоціями, почуттями, а також особистісними смислами. Це можуть бути як внутрішні, інтимні переживання, так і аналіз того, що відбувається навколо, тобто перехід свого внутрішнього світу в контент щоденникового запису. Але існує інший потенціал для контенту, який, на думку відомого психолога К. Левіна, має «спонукальний характер» - несе позитивно притягуючу валентність [12, с. 124]. Прикметно, що таким потенціалом є подієвість повсякденного життя. Формування К-П й інтересу до себе можливий лише за умови достовірної репрезентації того, що відбувається навколо нього у реальному просторі. У ЩД комунікантом-продуцентом $є$ автор. Він регулярно фіксує події, учасником яких був i які його найбільше вразили, надаючи досвіду, що знаходиться в безперервному русі, якоїсь обрамленої форми - фрейми.

Отже, винятковість комунікативної ситуації відкриває можливість для реалізації у ЩД таких завдань: автор розповідає про своє минуле життя, осмислюючи його і репрезентуючи відверті, не завжди упереджені оцінки. Він представляє ретроспективний погляд на своє існування, визначення певних закономірностей. ЩД набуває особливої поліфонічності: в умовах односторонньої діяльності пріоритетним стає взаємозв'язок між висловленнями і позиціями не тільки К-П і К-Р, а й різними К-П і К-Р між собою. Комунікативний простір у ЩД активно впроваджує у суспільну свідомість психологічні та поведінкові установки, цінності й пріоритети. У цьому полягає, з одного боку, вихід його функцій за межі практичної, прагматичної сфери, а з іншого, - та небезпека, яку вона потенційно несе в собі, оскільки $є$ тією ланкою комунікації, світоглядний, цінніснотворчий аспект якої малодосліджений. Поняття 
комунікативний простір у ЩД ще потребує детального аналізу й теоретичного обгрунтування на вербально-семантичному, когнітивному й прагматичному рівнях у різних галузях знань.

\section{Література}

1. Бахтин М. М. Проблема мовних жанрів // Бахтин М. М. Собр. соч. - М. : Російські словники, 1996. - Т.5 : Роботи 1940-1960 pp. - С. 159-206.

2. Барт Р. Введение в структурный анализ повествовательных текстов // Зарубежная эстетика и теория литературы XIX-XX вв. [Трактаты, статьи, эссе] / Р. Барт. - М. : Изд-во Московского университета, 1987.

3. Бубер М. Я и Ты / М. Бубер // Квинтэссенция : Филос. Альманах, 1991. - С. 296.

4. Ван Дейк Т. А. Язык. Познание. Коммуникация: пер. с англ. / Т. А. Ван Дейк / [сост. В. В. Петрова; под ред. В. И. Герасимова; Вступ. Статья Ю. Н. Караулова и. В. В. Петрова]. - М. : Прогресс, 1989. - 312 с.

5. Выготский Л. С. Собр. соч. : в 6 т. / Л. С. Выготский. - Т. 2. - М., 1982. C. 295-360.

6. Воля Олесь Щоденник. Сорок років. 1969-2009 / Олесь Воля. - К. : Аконіт, 2011. $-1208 \mathrm{c}$.

7. Гаспаров Б. М. Язык, память, образ : Лингвистика языкового существования / Б. М. Гаспаров. - М. : Новое лит. обозрение, 1996. - 352 с.

8. Гончар О. Т. Щоденники : у 3-х т.: Т. 2 (1968-1983) / О. Т. Гончар / [Упоряд., підгот. текстів, ілюстр. матеріалу В. Д. Гончар]. - К. : Веселка, 2003. - 607 с.

9. Гончар О. Т. Щоденники : у 3-х т. : Т.3 (1984-1995) / О. Т. Гончар / [Упоряд., підгот. текстів, ілюстр. матеріалу В. Д. Гончар]. - К. : Веселка, 2004. - 606 с.

10. Коваленко Л. М. «Ми - люди майбутнього, ми - не минулі». [Статті, рецензії, щоденники, спогади, поезії, листи] / Л. М. Коваленко / [Упоряд, Н. Л. Калениченко, О. Б. Поліщук; вступ. слово М. Г. Жулинського]. - Дніпродзержинськ : Видавничий дім «Андрій», 2008. - 512 с.

11. Кубрякова Е. С. Об установках когнитивной науки и актуальных проблемах когнитивной лингвистики / Е. С. Кубрякова // Вопросы языкознания. - 2004. - №1. - С. 6-17.

12. Левин К. Теория поля в социальных науках / К. Левин / Пер. с англ. - СПб. : Сенсор, 2000. - 368 c.

13. Леонтьев А. Н. Деятельность. Сознание. Личность / О. Н. Леонтьєв. - М. : Политиздат. - 1975. - 304 с.

14. Лотман Ю. М. Автокоммуникация «Я» и «Другой» как адресаты / Ю. М. Лотман. Внутри мыслящих миров. Человек - текст - семиосфера - история. M., 1996. - C. 36.

15. Муравьева Н. В. Язык конфликта / Н. В. Муравйова. - М. : Термика, 2006.

16. Пирогов К. Дневник : Общение с самим собой в пространстве тотальной коммуникации / К. Пирогов // Проблемы общения в пространстве тотальной коммуникации. Международные чтения по теории, истории и философии культуры. Вып. 6: Спб, 1998. - С. 204.

17. Почепцов Г. Г. Теория коммуникации / Г. Г. Почепцов. - М. : «Рефл-бук, К.: Ваклер», 2001. - 656 c. 
18. Прохоров Ю. Е. Концепт, текст, дискурс в структуре и содержании коммуникации : дис. ...д-ра філол. наук : 10.02 .01 / Ю. Е. Прохоров. - М. : Екатеринбург, 2006. - 338 с.

19. Радзиевская Т. В. Текст как результат безадресатной стратеги // Человеческий фактор в языке : Коммуникация, модальность, дейксис / Т. В. Радзиевская. -М.,1992. - С.103.

20. Радзиевская Т. В. Текст как результат безадресатной стратеги / Человеческий фактор в языке: Коммуникация, модальность, дейксис / Т. В. Радзиевская. - М.,1992. - С. 102.

21.Селіванова О. О. Сучасна лінгвістика : напрями та проблеми : [підручник] / О. О. Селіванова. - Полтава : Довкілля-К, 2008. - 712 с.

22. Сусов И. П. Лингвистическая прагматика / И. П. Сусов. - Винница : «Нова Книга», 2009. -273 с.

23. Танюк Л. С. Лінія життя (3 щоденників) : у 2 т. : Т. 2 : 1971 - 1980 / Худож.оформлювач І. В. Осипов. - Харків : Фоліо, 2004. - 558 с.

Стаття надійшла до редакції 06.09.2012 p. 